\title{
EFFECT OF TESTOSTERONE ENANTHATE HORMONES ON SOME PRODUCTION, PHYSIOLOGICAL TRAITS AND THEIR RESIDUE IN THE MEAT OF LOCAL RABBITS IN SULAYMANIYAH, IRAQ
}

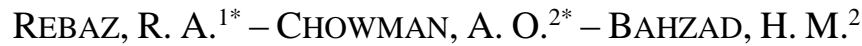 \\ ${ }^{I}$ Research center, Qrga Street University of Sulaimani Polytechnic, Sulaimaniah, Iraq \\ ${ }^{2}$ College of Agricultural Engineering Sciences, Bakrajo Street, University of Sulaimani, \\ Sulaimaniah, Iraq \\ ${ }^{*}$ Corresponding authors \\ e-mail: rebaz.ramazan@spu.edu.iq; phone: +96-477-1950-2597 \\ e-mail: choman.omer@univsul.edu.iq; phone:+96-477-0157-0015 \\ (e-mail: bahzad.mustafa@univsul.edu.iq; phone: +96-477-0152-2076) \\ (Received 6 ${ }^{\text {th }}$ Jul 2019; accepted $25^{\text {th }}$ Oct 2019)
}

\begin{abstract}
A total of 48 weaned male rabbits were randomly arrangement to evaluate the effects of the Testosterone Enanthate (TE) for four treatments: negative control-without injection, positive controlPhosphate-buffered saline PBS, (TE) 4 IU and 8 IU injected intramuscularly (B1 and B2, respectively). Body weight traits measured by weekly weighing for 72 days (slaughter weight) their body weight and average daily gains (ADG) were calculated, and were then slaughtered to assess the TE residues of meat. Blood samples were collected for measuring phosphate-buffered saline (CBC) count, ALT, AST, ALP, Growth Hormone $(\mathrm{GH})$ and Testosterone concentration The present study observed a significant increase in total BW gain for group B2 (8 IU), compared to negative control, positive control, and B1 group. The blood Testosterone concentration in the B2 group, significantly increased were higher than other treatment groups, at $2.73 \pm 0.26 \mathrm{ng} / \mathrm{dL}$. The TE residue in meat there was no significant difference after 30 days end of treatment. In conclusion, TE injection improves BW traits in male growing rabbits when injected with a double dose of TE, with the exception of some CBC counts and has a significant mitigating effect on stress parameters, and increasing effect on serum GH and Testosterone concentration, with no significant changes in the TE residue in the meat.
\end{abstract}

Keywords: buck rabbits, TE injection, body weight gain, $C B C$, testosterone concentration, TE residues

\section{Introduction}

Domestic rabbits, in recent years, have been identified as economy livestock of meat shortage in high human population developing countries. Animals Meat, including rabbit's meat, supply a valuable and palatable source of protein. Rabbit meat has a very good nutritive value, being comparatively high in protein, low in fat, calories and sodium, and so could bridge the wide gap in dietary protein intake (Adeyinka et al., 2007). Anabolic androgenic steroids (AAS) are synthetic derivatives of testosterone hormone in the male that have been adjusting to improve their anabolic rather than androgenic activity (Shahidi, 2001). The AAS effects promote protein synthesis, muscle growth and erythropoiesis (Mottram and George, 2000). Anabolic steroids are a class of steroid hormones based on the androgen testosterone and are recognized for their effects on building up muscle and are used as an enhancing drug (Thienpont et al., 1998). Anabolic steroids increase muscle size by the promotion of positive nitrogen balance by stimulating protein production and decreasing destruction (Guan et al., 2010). However, there is 
insufficient available information for their use in these animals. Recently, boldenone undecylenate (androgenic steroid) has been used in the growth improvement and conversion of food in food-producing animals. It is also well known for increasing vascularity in preparation for bodybuilding contests. It might also play an important role not only in controlling normal testicular development, but also in maintaining spermatogenesis and normal testicular function (Tousson et al., 2012). The use of the anabolic steroid (BOL) resulted in obvious improvement in the growth rate (Tousson et al., 2012). This effect could be attributed to the promotion of the body tissue building process by protein synthesis indirectly via stimulation of growth hormone, insulin-like growth factor secretion, and animal appetite (Ferreira et al., 1998) or reduction of glucocorticoid receptor levels and sensitivity to endogenous glucocorticoids; therefore, the strong growth promoting potency is based not only on its anabolic activity as an antiglucocorticoid (Melloni et al., 1997; Thienpont et al., 1998). However, there were some reports reviewed that the rabbits' growth performance was not affected by testosterone injection (Tawfeek et al., 1994). Administration of BOL to male rabbits at a dose of $(5 \mathrm{mg} / \mathrm{kg}$ body weight) had a positive and significant benefit on growth performance (feed efficiency, total and daily weight gain) and a significant increase in dressing percent (Mohammed et al., 2016). Nahed et al. (2010) reported that using of BOL in rabbit was not sufficient to confirm its use in rabbits although a considerable improvement of total weight gain, feed efficiency and feed conversion ratio were attained after application of BOL in the male rabbit. However, there is no reported in detail study on the effect of BOL on all carcass traits and blood parameters (Abdel-Hamid and Farahat, 2015). The double and the normal recommended dose positively increase serum total protein and globulin, while normal recommended dose apparently increases serum cholesterol and decrease plasma corticosterone level. The European Economic Community (EEC) banned the use of anabolic compounds as growth accelerators in food animals. While the United States Food and Drug Administration (USFDA) permitted the limited use of some hormones with natural origins (such as estradiol and testosterone) and some synthetic hormones (such as Zeranol and trenbolone) in animal husbandry (MacVinish and Galbraith, 1988; Sadek et al., 1998). Little work has been conducted in Iraq regarding the use of testosterone enanthate TE injection as a growth promoter and their residue in edible tissue. A report of Omar (2012), there were no significant differences among the three experimental groups in the TE residue of the cooked meat at 8 months of age, but their values were significantly lower than the fresh meat of Karadi lambs at the same period. A number of authors and official international committees proved that residues of natural steroidal hormones are not dangerous on the health of the consumer (JECFA, 1988; Lone and Van Ginkel, 1997; Galbraith, 2002). Testosterone is usually given in an injection vehicle with oestradiol, and as same with other steroid hormones, the testosterone injection do not differ than the natural hormone inside the body of the organism, and this hormone focused in the liver tissue and kidney, but in fat are the highest concentration of this hormone, When comparing the residues in treated animals and the natural ratios in animals without treatment, they have to be equal or close to it (Omar, 2012). As well as the content of the natural hormone and the testosterone in male sheep and goats is higher than females, although the consumer is preferred the meat of males on other meats. Hence, this study was performed to determine the effects of Two-doses administration of TE on body weight (BW), some blood biochemical parameters and testosterone residual effect of mature local male rabbits. 


\section{Materials and Methods}

Location and duration of the study: The present study was carried out at the Experimental farm of the University of Sulaimani Polytechnic, Halabja Technical Agriculture College, Halabja-Iraq, during spring (April to June) of 2017. A total of (48 bucks) weaned male rabbits (14 weeks old) of Local breed were randomly assigned to a completely randomized design arrangement of treatments (Four treat 12 bucks /treat: negative control-without injection, positive control injected intramuscularly by Phosphate-buffered saline PBS, Testosterone Enanthate (4 IU) injected intramuscularly (B1) and Testosterone Enanthate (8 IU) injected intramuscularly (B2). All rabbits were injected after 14 days of adaptation and repeated once after 30 days of the first injection. Bucks were housed in a semi-closed rabbitry housing system with does and kept in batteries of individual cages $(60 \times 50 \times 35 \mathrm{~cm})$ supplied with feeding hoppers made of galvanized steel sheet and nipples for an automatic drinker. A commercial concentrate pellets ration is introduced to bucks throughout the experiment (Table 1), containing $(16.91 \%)$ crude protein and $(2703 \mathrm{Kcal} / \mathrm{Kg} \mathrm{DM})$ ration metabolizable energy (ME) (NRC, 1977). Fresh and clean drinking water was supplied ad-libitum. The feed and the water were offered ad-libitum. All the bucks were grown under identical environmental and feeding conditions as well as the same stocking density. A photoperiod (12L:12D) from 0900 to $2100 \mathrm{~h}$ was used throughout the experimental period. The temperature was maintained at a range of $28-32^{\circ} \mathrm{C}$ inside the house.

Table 1. Ingredient Composition Of The Diet During The Experiment Period

\begin{tabular}{c|c}
\hline Ingredient & $\%$ \\
Maize & 35 \\
Wheat Grain & 25 \\
Soybean Meal & 10 \\
Sesame Oil & 15 \\
Wheat Bran & 14 \\
Common Salt & 0.6 \\
Premix & 0.25 \\
Dl. Methionine & 0.15 \\
Total & 100 \\
Crud Protein (\%) & 16.91 \\
Metabolizable Energy Kcal/Kg Dm & 2703 \\
\hline
\end{tabular}

Traits Measurements: Traits measured were; body weights: fryer rabbits were weighed weekly until 72 (slaughter weight) days and weights were recorded in grams. Body weight gain: calculated as differences between two successive different weights. Average daily gains ADG: calculated as the differences between two successive different weights at two different periods divided by the number of days between the two weights.

Blood parameters: Blood samples were collected twice in the experiment, before treatment and after one month after the first injection. The samples were taken in two test tubes, one with an anticoagulant for measuring CBC count levels and the other one without using anticoagulant to separate the serum for measuring ALT, AST, ALP, Growth Hormone $(\mathrm{GH})$ and Testosterone concentration. Plasma and serum samples were stored at $-20^{\circ} \mathrm{C}$ until assayed. ALT, AST, ALP, Growth Hormone (GH) and Testosterone concentration were measured using commercial kits. For CBC levels we used Hematology analyzer (URIT 2900z, Vet Z plus, China), and for enzymes activity, we 
used Biochemical Analyser (Floxer pro. S, China), and Hormone concentration by (MINI VIDAS ${ }^{\circledR}$, France). For each treatment, five samples were assayed.

TE residue in meat: After slaughtering the bucks, 30 days after the last injection of the experiment. $500 \mathrm{gm}$ of muscle were taken and placed in polyethylene bags and stored at $-18^{\circ} \mathrm{C}$. Semimembranosus (SM) from pelvic limb leg was dissected according to the procedure of Butterfield et al. (1983). The surfaces of the muscles were cleaned from all fat and connective tissue. Quantitative determination of testosterone concentration $(\mu \mathrm{g} / \mathrm{kg}=\mathrm{ng} / \mathrm{mL})$ was carried out by using Radioimmunoassay (RIA) by using (cobas e 411 analyzer, made in Germany). The analytic sensitivity of the assay was $0.025 \mathrm{ng} / \mathrm{mL}$.

Statistical analysis: Complete Randomized Design (CRD) procedures of XLstat. (7.5.2, 2010) in one-way ANOVA were used to determine the effects of Testosterone Enanthate TE and injection effect on the body weight characteristics, blood parameters, and TE residue. Group differences were determined using Duncan's multiple range tests at $(\mathrm{p} \leq 0.05)$ (Duncan, 1955).

\section{Results}

The effect of Testosterone Enanthate-TE hormone on growth performance parameters of local male rabbits was showed in Table 2. The results revealed that TE injection in male rabbits resulted not significant ( $p>0.05$ ) different among groups, in initial $\mathrm{BW}$, final $\mathrm{BW}$ gain, average daily gain ADG, and the high weight record were seen in B2 group for final BW and ADG $(1593.3 \pm 41.5$ and 6.292 \pm 0.384$) \mathrm{gm}$, respectively. But there were a significant $(\mathrm{p}<0.05)$ different in total BW gain for group B2 (8 IU), which recorded (377.5 \pm 23.0$)$ gm compared to negative control, positive control and B1 group, which were recorded $(281.2 \pm 60.8) \mathrm{gm},(271.2 \pm 32.5) \mathrm{gm}$ and $(284.1 \pm 37.1) \mathrm{gm}$, respectively. The best results were for the group (B2) in total BW and ADG increased in the ADG for groups (B1) and (B2) compared with the control.

Table 2. Effect of te hormone on growth performance parameters of male rabbits

\begin{tabular}{c|c|c|c|c}
\hline \multirow{2}{*}{ Parameters } & \multicolumn{4}{|c}{ TREATMENT GROUPS } \\
\cline { 2 - 5 } & $\begin{array}{c}\text { NEGATIVE } \\
\text { CONTROL }\end{array}$ & $\begin{array}{c}\text { POSITIVE } \\
\text { CONTROL }\end{array}$ & B1 & \multirow{2}{*}{ B2 } \\
\hline Initial Bw (gm) & $1225.0 \pm 58.2^{\mathrm{a}}$ & $1260.8 \pm 37.0^{\mathrm{a}}$ & $1246.6 \pm 30.8^{\mathrm{a}}$ & $1194.1 \pm 26.1^{\mathrm{a}}$ \\
Final Bw (gm) & $1521.6 \pm 44.8^{\mathrm{a}}$ & $1556.6 \pm 25.4^{\mathrm{a}}$ & $1516.6 \pm 36.8^{\mathrm{a}}$ & $1593.3 \pm 41.5^{\mathrm{a}}$ \\
Total Bw Gain (gm) & $281.2 \pm 60.8^{\mathrm{b}}$ & $271.2 \pm 32.5^{\mathrm{b}}$ & $284.1 \pm 37.1^{\mathrm{b}}$ & $377.5 \pm 23.0^{\mathrm{a}}$ \\
ADG (gm) & $4.688 \pm 1.013^{\mathrm{a}}$ & $4.521 \pm 0.543^{\mathrm{a}}$ & $4.736 \pm 0.620^{\mathrm{a}}$ & $6.292 \pm 0.384^{\mathrm{a}}$ \\
\hline
\end{tabular}

-Negative Control: Without Injection

-Positive Control: Injected Intramuscularly With Bps (0.25 Ml)

-B1: Received (4 Iu) Intramuscular Injections Of T.E

-B2: Received (8 Iu) Intramuscular Injections Of T.E

-Bw: Body Weight; ADG: Average Daily Gain

${ }^{\text {abc }}$ Means In The Same Row With Different Superscripts Are Significantly Different At $(\mathrm{P}<0.05)$

Effects of dose of TE and the injection effect on complete blood picture levels parameters were summarized in Table 3. Statistically, no significant differences ( $p>0.05)$ were recorded before treatment for complete blood picture levels parameters. While, there were significant differences $(\mathrm{p}<0.05)$ were observed for control groups (negative and positive) compared to TE hormone injection groups after treatment for $\mathrm{Hb}(\mathrm{g} / \mathrm{dL}), \mathrm{RBC}$ $\left(10^{6} \mathrm{xUL}\right)$ and $\mathrm{HCT}(\%)$. The hormone injection groups (TE injection) significantly 
$(\mathrm{p}<0.05)$ decrease the $\mathrm{Hb}$ concentration, which was $(13.0 \pm 0.4 \mathrm{~g} / \mathrm{dL}$ and $13.0 \pm 0.4 \mathrm{~g} / \mathrm{dL})$ for B1 and B2 respectively, compared to positive control $(14.8 \pm 0.8 \mathrm{~g} / \mathrm{dL})$. Furthermore, the B2 group (8 IU) significantly $(\mathrm{p}<0.05)$ decrease in RBC and HCT, when compared to positive control $(6.97 \pm 0.34) 10^{6} \mathrm{xUL}$ and $(46.1 \pm 2.4) \%$, respectively. While MCV of the negative control was significant $(\mathrm{p}<0.05)$ overpowered $(69.4 \pm 0.1) \mu \mathrm{L}$ on other injection groups. But, there was no significant $(\mathrm{p}>0.05)$ difference between control and all injected groups for platelet count PLT $\left(10^{3} \mathrm{x}\right.$ cells/mcL) count.

Table 3. Changes in the complete blood picture levels in different groups under study

\begin{tabular}{|c|c|c|c|c|}
\hline \multirow{2}{*}{ Items } & \multicolumn{4}{|c|}{$\begin{array}{l}\text { TREATMENT GROUPS } \\
\end{array}$} \\
\hline & Negative Control & Positive Control & $\mathrm{B} 1$ & $\mathrm{~B} 2$ \\
\hline \multicolumn{5}{|c|}{ Before treatment } \\
\hline $\mathrm{Hb}(\mathrm{g} / \mathrm{dl})$ & $13.6 \pm 0.6^{\mathrm{a}}$ & $13.1 \pm 1.4 \mathrm{a}$ & $13.8 \pm 0.2^{\mathrm{a}}$ & $13.1 \pm 0.3^{\mathrm{a}}$ \\
\hline $\operatorname{RBC}\left(10^{6} x u l\right)$ & $6.02 \pm 0.33^{\mathrm{a}}$ & $6.23 \pm 0.75 \mathrm{a}$ & $6.59 \pm 0.35^{\mathrm{a}}$ & $6.12 \pm 0.22^{\mathrm{a}}$ \\
\hline HCT $(\%)$ & $42.7 \pm 2.4^{\mathrm{a}}$ & $41.3 \pm 4.5 \mathrm{a}$ & $42.9 \pm 0.9^{\mathrm{a}}$ & $39.8 \pm 1.2^{\mathrm{a}}$ \\
\hline $\operatorname{MCV}(\mu \mathrm{l})$ & $70.8 \pm 0.5^{\mathrm{a}}$ & $61.0 \pm 5.2 \mathrm{a}$ & $65.4 \pm 2.1^{\mathrm{a}}$ & $65.2 \pm 0.9^{\mathrm{a}}$ \\
\hline МСH (\%) & $22.6 \pm 0.1^{\mathrm{a}}$ & $19.4 \pm 1.5^{\mathrm{a}}$ & $21.1 \pm 0.6^{\mathrm{a}}$ & $21.4 \pm 0.3^{\mathrm{a}}$ \\
\hline $\operatorname{MCHC~}(\%)$ & $32.0 \pm 0.2^{\mathrm{a}}$ & $29.1 \pm 2.5^{\mathrm{a}}$ & $32.2 \pm 0.3^{\mathrm{a}}$ & $32.9 \pm 0.1^{\mathrm{a}}$ \\
\hline PLT $\left(10^{3} \times\right.$ Cells/Mcl $)$ & $213.3 \pm 6.3^{\mathrm{a}}$ & $216.2 \pm 41.2^{\mathrm{a}}$ & $220.5 \pm 19.5^{\mathrm{a}}$ & $177.0 \pm 45.2^{\mathrm{a}}$ \\
\hline RDW $(\%)$ & $15.1 \pm 0.4^{\mathrm{a}}$ & $13.4 \pm 1.3^{\mathrm{a}}$ & $15.6 \pm 0.58^{\mathrm{a}}$ & $14.3 \pm 0.1^{\mathrm{a}}$ \\
\hline \multicolumn{5}{|c|}{ After treatment } \\
\hline Hb (g/dl) & $14.1 \pm 0.5^{\mathrm{ab}}$ & $14.8 \pm 0.8^{\mathrm{a}}$ & $13.0 \pm 0.4^{\mathrm{b}}$ & $13.0 \pm 0.4^{\mathrm{b}}$ \\
\hline $\operatorname{RBC}\left(10^{6} \mathrm{xul}\right)$ & $6.45 \pm 0.14^{\mathrm{ab}}$ & $6.97 \pm 0.34^{\mathrm{a}}$ & $6.48 \pm 0.17^{\mathrm{ab}}$ & $6.02 \pm 0.13^{\mathrm{b}}$ \\
\hline HCT $(\%)$ & $44.8 \pm 1.1^{\mathrm{ab}}$ & $46.1 \pm 2.4^{\mathrm{a}}$ & $42.3 \pm 0.5^{\mathrm{ab}}$ & $40.4 \pm 1.1^{\mathrm{b}}$ \\
\hline $\operatorname{MCV}(\mu \mathrm{l})$ & $69.4 \pm 0.1^{\mathrm{a}}$ & $66.1 \pm 0.8^{\mathrm{b}}$ & $65.4 \pm 0.9^{\mathrm{b}}$ & $67.0 \pm 0.3^{\mathrm{b}}$ \\
\hline MCH (\%) & $21.8 \pm 0.3^{\mathrm{a}}$ & $21.2 \pm 0.1^{\mathrm{a}}$ & $20.1 \pm 0.4^{\mathrm{b}}$ & $21.6 \pm 0.3^{\mathrm{a}}$ \\
\hline MCHC $(\%)$ & $31.4 \pm 0.4^{\mathrm{ab}}$ & $32.2 \pm 0.2^{\mathrm{a}}$ & $30.7 \pm 0.3^{\mathrm{b}}$ & $32.2 \pm 0.2^{\mathrm{a}}$ \\
\hline PLT $\left(1^{3} \times\right.$ Cells/Mcl $)$ & $233.0 \pm 4.0^{\mathrm{a}}$ & $276.3 \pm 31.6^{\mathrm{a}}$ & $303.0 \pm 17.9^{\mathrm{a}}$ & $258.0 \pm 60.4^{\mathrm{a}}$ \\
\hline RDW $(\%)$ & $15.9 \pm 0.3^{\mathrm{ab}}$ & $15.6 \pm 0.5^{\mathrm{ab}}$ & $14.6 \pm 0.1^{\mathrm{b}}$ & $17.3 \pm 1.1^{\mathrm{a}}$ \\
\hline
\end{tabular}

-Negative Control: Without injection.

-Positive Control: injected intramuscularly with BPS $(0.25 \mathrm{ml})$.

-B1: received (4 IU) intramuscular injections of T.E.

-B2: received (8 IU) intramuscular injections of T.E.

-Hb: hemoglobin; RBC: red blood cell; HCT: hematocrit; MCV: mean corpuscular volume; $\mathrm{MCH}$ : mean corpuscular hemoglobin; MCHC: mean corpuscular hemoglobin concentration; PLT: platelet count; RDW: red cell distribution width.

${ }_{-}^{\mathrm{abc}}$ Means in the same row with different superscripts are significantly different at $(\mathrm{p}<0.05)$.

The results of Table 4 demonstrated that changes in Leukocytes levels changed significantly $(\mathrm{p}<0.05)$ after TE hormone treated. Before treatment there were no significant differences $(\mathrm{p}>0.05)$ in the leukocytes levels, on the other hand, we recorded significant differences $(\mathrm{p}<0.05)$ in WBC count, Lymphocyte \%, Monocytes \%, Neutrophil\%, Mean platelet volume (MPV\%) and platelet distribution width (PDW). The TE injection increased the WBC count significantly ( $<<0.05)$, which high count recorded in B1 (4 IU, TE), and the highly significant value for lymphocyte and monocyte percent were recorded in B2 (8 IU) (61.0 $\pm 1.0 \%$ and $0.75 \pm 0.02 \%$, respectively). Conversely, the neutrophils count significantly $(\mathrm{p}<0.05)$ higher in BPS injection (Positive Control) $(59.6 \pm 3.0 \%)$. Also, the significant level was seen in MPV and PDW for B2 injection, which was $6.05 \pm 0.02 \%$ and $9.10 \pm 0.44 \%$, respectively. As well, B1 injection significantly differenced too in PDW $(8.60 \pm 0.01 \%)$, when they compared to negative and positive control $(7.50 \pm 0.01$ and $7.63 \pm 0.02$, respectively). 
The comparison between the injection groups and negative control in the concentration of ALT, AST, ALP, Growth Hormone GH and Testosterone levels in the local rabbit are summarized in Table 5. Indeed, no significant differences were seen before treatment in all parameters, except in B1 treatment for AST and ALP levels. The AST recorded high level in B1 (39.0 $\pm 1.6 \mathrm{IU} / \mathrm{L})$. And ALP recorded less level in B1 $(79.0 \pm 1.2 \mathrm{IU} / \mathrm{L})$ when they compared to other treatments. After treatment, the parameters level change, the significant record seen in ALT, GH and testosterone concentration for B2 (8 IU) TE injection. The significant level for ALT recorded (69.5 $\pm 9.4 \mathrm{IU} / \mathrm{L})$, as compared to negative control, positive control and B1 injection. The GH concentration recorded significantly $(\mathrm{p}<0.05)$ higher level $(0.32 \pm 0.01 \mathrm{ng} / \mathrm{dL})$ at B2 (8 IU) TE injection when it compared to negative control and positive control $(0.24 \pm 0.01$ and $0.28 \pm 0.01 \mathrm{ng} / \mathrm{dL}$, respectively). As well as, the Testosterone concentration in the B2 group, significantly $(\mathrm{p}<0.05)$ increased and higher than other treatments groups, which recorded $(2.73 \pm 0.26 \mathrm{ng} / \mathrm{dL})$. And the other groups recorded significant differences for negative control, positive control and B1(4 IU) TE injection, which were $(0.60 \pm 0.06,0.83 \pm 0.10$ and $1.28 \pm 0.15 \mathrm{ng} / \mathrm{dL}$ ).

Table 4. Changes in the leukocyte levels in different groups under study

\begin{tabular}{c|c|c|c|c}
\hline \multirow{2}{*}{ Items } & \multicolumn{4}{|c}{ TREATMENT GROUPS } \\
\cline { 2 - 5 } & Negative Control & Positive Control & B1 & B2 \\
\hline \multicolumn{4}{c}{ Before treatment } \\
\hline WBC (10\%xul) & $3.33 \pm 0.63^{\mathrm{a}}$ & $2.76 \pm 0.49^{\mathrm{a}}$ & $4.50 \pm 1.07^{\mathrm{a}}$ & $4.75 \pm 0.85^{\mathrm{a}}$ \\
Lym. (\%) & $75.5 \pm 1.8^{\mathrm{a}}$ & $56.4 \pm 9.2^{\mathrm{a}}$ & $57.6 \pm 11.9^{\mathrm{a}}$ & $64.3 \pm 4.5^{\mathrm{a}}$ \\
Mon. (\%) & $7.86 \pm 3.02^{\mathrm{a}}$ & $0.87 \pm 0.67^{\mathrm{a}}$ & $0.27 \pm 0.08^{\mathrm{a}}$ & $0.50 \pm 0.14^{\mathrm{a}}$ \\
Neu. (\%) & $16.0 \pm 1.1^{\mathrm{a}}$ & $32.2 \pm 9.8^{\mathrm{a}}$ & $47.9 \pm 11.3^{\mathrm{a}}$ & $34.0 \pm 4.41^{\mathrm{a}}$ \\
MPV (\%) & $6.26 \pm 0.06^{\mathrm{a}}$ & $6.05 \pm 0.71^{\mathrm{a}}$ & $6.35 \pm 0.05^{\mathrm{a}}$ & $6.47 \pm 0.31^{\mathrm{a}}$ \\
PCT & $0.133 \pm 0.003^{\mathrm{a}}$ & $0.144 \pm 0.030^{\mathrm{a}}$ & $0.331 \pm 0.142^{\mathrm{a}}$ & $0.111 \pm 0.026^{\mathrm{a}}$ \\
PDW & $9.50 \pm 0.10^{\mathrm{a}}$ & $9.85 \pm 1.11^{\mathrm{a}}$ & $10.48 \pm 0.15^{\mathrm{a}}$ & $10.62 \pm 0.70^{\mathrm{a}}$ \\
\hline \multicolumn{5}{|c}{ After treatment } \\
\hline WBC (10\%xul) & $4.65 \pm 0.26^{\mathrm{b}}$ & $5.16 \pm 0.63^{\mathrm{a}}$ & $6.15 \pm 0.10^{\mathrm{a}}$ & $4.65 \pm 0.42^{\mathrm{b}}$ \\
Lym. (\%) & $55.2 \pm 2.0^{\mathrm{a}}$ & $33.3 \pm 1.1^{\mathrm{b}}$ & $55.4 \pm 7.7^{\mathrm{a}}$ & $61.0 \pm 1.0^{\mathrm{a}}$ \\
Mon. (\%) & $0.45 \pm 0.10^{\mathrm{b}}$ & $0.33 \pm 0.08^{\mathrm{b}}$ & $0.30 \pm 0.04^{\mathrm{b}}$ & $0.75 \pm 0.02^{\mathrm{a}}$ \\
Neu. (\%) & $42.1 \pm 1.8^{\mathrm{b}}$ & $59.6 \pm 3.0^{\mathrm{a}}$ & $39.8 \pm 6.2^{\mathrm{b}}$ & $34.0 \pm 1.2^{\mathrm{b}}$ \\
MPV (\%) & $5.75 \pm 0.02^{\mathrm{b}}$ & $5.56 \pm 0.02^{\mathrm{c}}$ & $5.70 \pm 0.04^{\mathrm{b}}$ & $6.05 \pm 0.02^{\mathrm{a}}$ \\
PCT & $0.134 \pm 0.002^{\mathrm{a}}$ & $0.153 \pm 0.018^{\mathrm{a}}$ & $0.173 \pm 0.011^{\mathrm{a}}$ & $0.155 \pm 0.037^{\mathrm{a}}$ \\
PDW & $7.50 \pm 0.01^{\mathrm{b}}$ & $7.63 \pm 0.02^{\mathrm{b}}$ & $8.60 \pm 0.01^{\mathrm{a}}$ & $9.10 \pm 0.44^{\mathrm{a}}$ \\
\hline
\end{tabular}

-Negative Control: Without injection.

-Positive Control: injected intramuscularly with BPS $(0.25 \mathrm{ml})$.

-B1: received (4 IU) intramuscular injections of T.E.

-B2: received (8 IU) intramuscular injections of T.E.

-WBC: white blood cell; Lym.: lymphocyte; Mon.: monocyte; New.: neutrophil; MPV: Mean platelet volume; PCT: procalcitonin test; PDW: platelet distribution width.

${ }^{\text {abc }}$ Means in the same row with different superscripts are significantly different at $(\mathrm{p}<0.05)$.

The results of TE residues in bucks' meat after 30 days of treatment are presented in Figure 1. Significant differences were not seen in the testosterone residue of the fresh meat, while there was no significant $(\mathrm{P}>0.05)$ increase in the TE residue in the fresh meat of B1 and B2 group intramuscular injections of TE with 4IU and 8IU (0.093 and $0.134 \mu \mathrm{g} / \mathrm{kg}$ ) and as compared to the negative and positive groups which were 0.086 and $0.061 \mu \mathrm{g} / \mathrm{kg}$, respectively Figure 1 . 


$$
-15283 \text { - }
$$

Table 5. Changes in the concentrations of alt, ast, alp, growth hormone and testosterone levels in different groups under study

\begin{tabular}{|c|c|c|c|c|}
\hline \multirow{2}{*}{ Items } & \multicolumn{4}{|c|}{ TREATMENT GROUPS } \\
\hline & Negative Control & Positive Control & $\mathrm{B} 1$ & B2 \\
\hline \multicolumn{5}{|c|}{ Before treatment } \\
\hline ALT (IU /l) & $59.0 \pm 1.6^{\mathrm{a}}$ & $55.0 \pm 10.2^{\mathrm{a}}$ & $56.0 \pm 1.2^{\mathrm{a}}$ & $54.6 \pm 1.2^{\mathrm{a}}$ \\
\hline $\operatorname{AST}(\mathbf{I U} / \mathbf{l})$ & $34.0 \pm 4.4^{\mathrm{ab}}$ & $29.0 \pm 2.4^{\mathrm{b}}$ & $39.0 \pm 1.6^{\mathrm{a}}$ & $35.9 \pm 1.4^{\mathrm{ab}}$ \\
\hline $\operatorname{ALP}(I U / \mathbf{l})$ & $158.3 \pm 3.8^{\mathrm{a}}$ & $112.3 \pm 22.2^{\mathrm{a}}$ & $79.0 \pm 1.2^{\mathrm{b}}$ & $174.4 \pm 34.3^{\mathrm{a}}$ \\
\hline GH $(\mathbf{n g} / \mathbf{d l})$ & $0.26 \pm 0.02^{\mathrm{a}}$ & $0.32 \pm 0.02^{\mathrm{a}}$ & $0.15 \pm 0.02^{\mathrm{a}}$ & $0.27 \pm 0.01^{\mathrm{a}}$ \\
\hline Testosterone (ng/dl) & $0.45 \pm 0.02^{\mathrm{a}}$ & $0.86 \pm 0.12^{\mathrm{a}}$ & $0.60 \pm 0.12^{\mathrm{a}}$ & $0.70 \pm 0.14^{\mathrm{a}}$ \\
\hline \multicolumn{5}{|c|}{ After treatment } \\
\hline ALT (IU /I) & $41.0 \pm 2.7^{b}$ & $39.9 \pm 1.1^{\mathrm{b}}$ & $50.8 \pm 3.0^{\mathrm{b}}$ & $69.5 \pm 9.4^{\mathrm{a}}$ \\
\hline $\operatorname{AST}(\mathbf{I U} / \mathbf{l})$ & $25.6 \pm 0.9^{\mathrm{a}}$ & $25.5 \pm 0.7^{\mathrm{a}}$ & $25.1 \pm 2.1^{\mathrm{a}}$ & $28.7 \pm 3.0^{\mathrm{a}}$ \\
\hline $\operatorname{ALP}(I U / 1)$ & $108.6 \pm 4.0^{\mathrm{a}}$ & $117.0 \pm 16.1^{\mathrm{a}}$ & $107.7 \pm 13.9^{\mathrm{a}}$ & $111.5 \pm 12.0^{\mathrm{a}}$ \\
\hline GH (ng/dl) & $0.24 \pm 0.01^{\mathrm{c}}$ & $0.28 \pm 0.01^{\mathrm{b}}$ & $0.29 \pm 0.01^{\mathrm{ab}}$ & $0.32 \pm 0.01^{\mathrm{a}}$ \\
\hline Testosterone (ng/dl) & $0.60 \pm 0.06^{\mathrm{c}}$ & $0.83 \pm 0.10^{\mathrm{bc}}$ & $1.28 \pm 0.15^{\mathrm{b}}$ & $2.73 \pm 0.26^{\mathrm{a}}$ \\
\hline
\end{tabular}

-Negative Control: Without injection.

-Positive Control: injected intramuscularly with BPS $(0.25 \mathrm{ml})$.

-B1: received (4 IU) intramuscular injections of T.E.

-B2: received (8 IU) intramuscular injections of T.E.

-ALT: alanine aminotransferase; AST: aspartate aminotransferase; ALP: alkaline phosphatase level; GH: growth hormone.

${ }_{\text {abc }}$ Means in the same row with different superscripts are significantly different at $(\mathrm{p}<0.05)$.

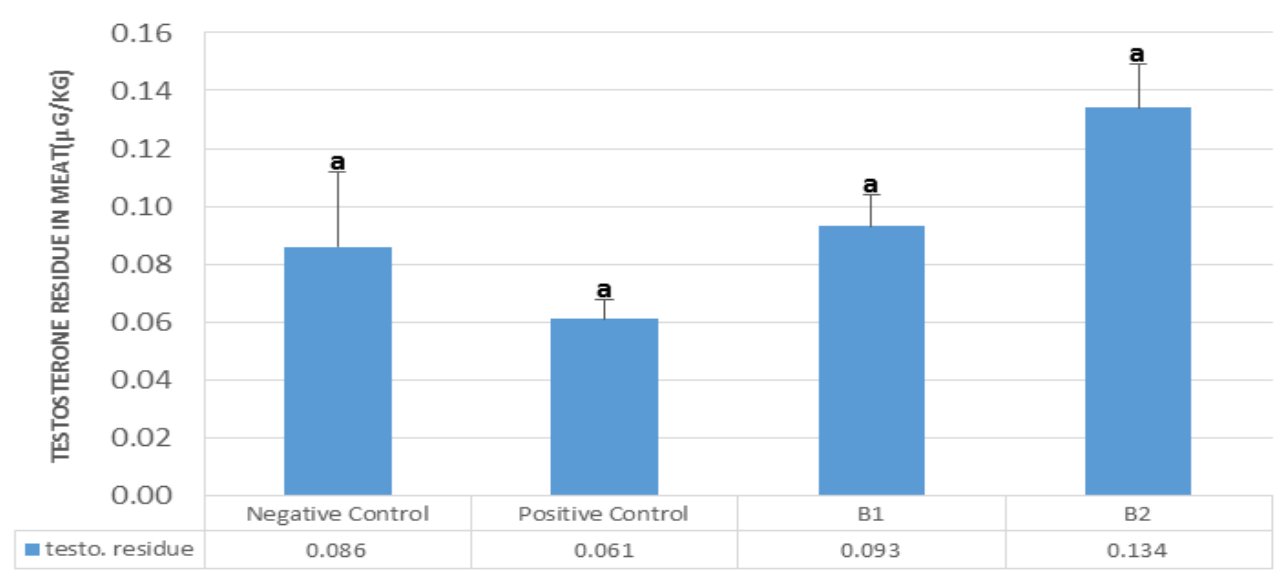

Figure 1. Concentration residue of Testosterone Enanthate in meat of local rabbit bucks

(Negative Control: Without injection; Positive Control: injected intramuscularly with BPS $(0.25$ ml); B1: received (4 IU) intramuscular injections of T.E.B2: received (8 IU) intramuscular injections of T.E. ${ }^{a}$ Means in the same row with different superscripts are significantly different at $(p<0.05))$

\section{Discussions}

The growth performance improved in treated groups (B1 and B2) proportional to the control groups (Table 2), which is consistent with antecedent reports (Thabet et al., 2010). The same observation was described by Tousson et al. (2012) and Mohammed et al. (2016) when they use anabolic steroid (BOL, boldenone undecylenate), who stated that the use of the (BOL) give rise to an obvious improvement in the growth rate. This effect could be imputed to the promotion of the body tissue building process by protein synthesis 
indirectly via stimulation of growth hormone, insulin-like growth factor secretion, and animal appetite (Ferreira et al., 1998) or reduction of glucocorticoid receptor levels and sensitivity to endogenous glucocorticoids; therefore, the strong growth promoting potency is based not only on its anabolic activity as an antiglucocorticoid (Melloni et al., 1997; Thienpont et al., 1998). However, Tawfeek et al. (1994) reported that the rabbits' growth performance was not affected by testosterone injection.

The obtained findings in Table 3 agree with the results of Battista et al. (2003) and Liewellyn (2006) who founded that, testosterone dosage and its entrance to the body caused an increase in hematocrit \%. Moreover, Gagnon et al. (1994) founded that, the raised hematocrit and hemoglobin persist for extended periods after the cessation of androgenic steroids use. Similarly, Ahmed (2014) recorded significant increase RBCs, $\mathrm{Hb}$, and PCV in boldenone administered groups as compared to the control one. These results may be imputed to that; anabolic steroids could stimulate erythropoiesis (Gabr et al., 2009) through the direct positive effect of androgenic steroids on erythropoietin production in renal tissues (Liewellyn, 2006). This reaction is mainly driven by the androgen receptor stimulation in renal tissue, leading to the stimulation of erythropoietin production directly. Androgens may also influence the stem cells directly, perhaps by enhancing the stem cell's responsiveness to erythropoietin (Snyder, 2008).

Anabolic steroids could spur erythropoiesis, a mechanism that may occur by stimulating erythropoietic-stimulating factor (Gabr et al., 2009). These results (Table 4) are in agreement with Urhausen et al. (2003) and Gabr et al. (2009) who adduced that the liver and kidney functions increased significantly after intramuscular BOL undecylenate injection on weaned male lambs. Similarly, current results are in conformity with Dickerman et al. (1999) and Tousson et al. (2011a, 2011b) who noticed that the anabolic steroid-induced hepatotoxicity. Following the same opinions, Istasse et al. (1988) reported that $17 \mathrm{~b}$-estradiol increased nitrogen retention and decreased blood urea nitrogen concentrations. Injection of the anabolic steroid BOL induced changes in oxidative stress biomarker levels and antioxidant defense systems in rabbit liver and kidney (El-Moghazy et al., 2012).

In agreement with our findings (Table 5), in treated groups with anabolic androgenic steroid, the serum testosterone levels were significantly higher than that in the control group (Urhausen et al., 2003; Takahashi et al., 2004; Gabr and Shaker, 2006; Gabr et al., 2009; Ishak and Omer, 2014). Simontacchi et al. (2004) reported that administration of testosterone derivatives alone did not induce plasma testosterone levels. Also, Shimomura et al. (2005) showed that the treatment of rats with ethinyloestradiol alone the testosterone levels decreased significantly in serum and the testis. Our results are in agreement with Omar (2012) who studied the effects of Testosterone Enanthate injection on testis function, live weight gain and carcass traits of Karadi lamb rams. The significant increase in testosterone observed in (B1 and B2) of mature rabbits treated by boldenone may be in accordance with the findings of Urhausen et al. (2003), Takahashi et al. (2004) and Gabr and Shaker (2006) who founded that, serum testosterone levels in treated groups with androgenic steroids were significantly higher than that in the control group. These results shore up former reports (Gabr et al., 2009; Tousson et al., 2012) who mentioned that an increase of testosterone may be attributed to the synthesis of a substrate related to the primary male sex hormone.

In the present study, results of TE residue in the fresh meat after 30 days stopped injection, showed no significant difference between the groups (Figure 1), these results are in contrast with the finding of Paris et al. (2006), when they found a significant 
difference between the treated and non-treated lambs of the same age group, for example, the anabolic steroids in the muscle, liver, kidneys and adipose tissue. While there was an increase of TE residue in the fresh meat of the male rabbit treated with 4IU TE and those treated with 8IU TE as compared to control groups. The main possible mechanism for these results could be the testicular hormone especially testosterone which let the male be superior in TE residue than the control groups (Omar, 2012). The exogenous testosterone has also been considered as the other reason for elevating TE residue in fresh meat of the intact animal as compared to the castrated. To our knowledge detained from available literature, no other previous study dealt with TE injection on rabbit male and their residue in meat. These differences may be related to exogenous testosterone in addition to testicular hormone especially testosterone which produce mainly by leydig cells. As well as increasing TE residue in fresh meat, which could be reduced in the cooking process (Omar, 2012).

\section{Conclusion}

From the obtained results it could be concluded that, although intramuscular injection of Testosterone Enanthate espesioly B2 (8IU) to male local rabbits enhances body gain and increased some hematological parameters, it increased oxidative stresses biomarkers levels, pro-inflammatory cytokines and creatinine indicating side effects on the liver and kidneys. And a no significant deferences in TE residue was seen in the fresh meat after 30 days of injection.

Acknowledgments. The authors gratefully thank the University of Sulaimani Polytechnic, Halabja Technical Agriculture College, for performing a place to conduct research in the Experimental farm of the Halabja Technical Agriculture College.

\section{REFERENCES}

[1] Abdel-Hamid, T. M., Farahat, M. H. (2015): Carcass traits and some blood stress parameters of summer stressed growing male rabbits of different breeds in response to boldenone undecylenate. - J. Adv. Vet. Anim. Res. 2: 263-270.

[2] Adeyinka, I. A., Akanwa, C. L., Iyeghe-Erakpotobor, G. T., Adeyinka, F. D., Orunmuyi, M. (2007): Factors affecting some traits of economic importance in rabbit in a tropical environment of Northern Nigeria. - J. Biol. Sci. 7: 425-428.

[3] Ahmed, N. F. N. (2014): Effect of Boldenone Undecylenate on Hematological and Biochemical Parameters in Veal Calves. - Global Veterinaria 13(6): 1092-1096.

[4] Battista, V., Combs, J., Warne, W. J. (2003): Asynchronous bilateral Achilles tendon ruptures and androstenediol use. - Am. J. Sports Med. 31: 1007-1009.

[5] Butterfield, R. M., Griffiths, D. A., Thompson, J. M., Zamora, J., James, A. M. (1983): Changes in body composition relative to weight and maturity in large and small strains of Australian Merino rams. 1. Muscle, bone and fat. - Animal production 36: 29-37.

[6] Dickerman, R. D., Pertusi, R. M., Zachariah, N. Y., Dufour, D. R., McConathy, W. J. (1999): Anabolic steroidinduced hepatotoxicity: is it overstated? - Clinical J. Sport Med. 9: 34-39.

[7] Duncan, D. B. (1955): Multiple range and multiple f-test. - Biometrix 11: 1-24.

[8] El-Moghazy, M., Tousson, E., Sakeran, M. (2012): Changes in the hepatic and renal structure and function after a growth promoter Boldenone injection in Rabbits. - Animal Biology 62: 171-180. 
[9] Ferreira, I. M., Verreschi, I. T., Nery, L. E., Goldstein, R. S., Zamel, N., Brooks, D. (1998): The influence of 6 months of oral anabolic steroids on body mass and respiratory muscles in undernourished COPD patients. - Chest 114: 19-28.

[10] Gabr, F. I., Shaker, M. H. (2006): Effect of anabolic steroids (Boldenone Undecylenate) on metabolic, hormones and reproductive performance of mature rams. - Journal of Egyptian Veterinary Medical Association 66: 235-248.

[11] Gabr, F., Abo El-Maaty, T., Amal, M., Aotifa, A. M. (2009): Effects of growth promoter boldenone undecylenate on weaned male lambs. - Nature and Science 7(3): 61-69.

[12] Gagnon, D. R., Zhang, T. J., Brand, F. N., Kannel, W. B. (1994): Hematocrit and Risk of Cardiovascular Disease - the Framingham Study: a 34-Year Follow Up. - Am. Heart J. 127: 674-682.

[13] Galbraith, H. (2002): Hormones in international meat production: biological, sociological and consumer issues. - Nut. Res. Rev. 15: 293-314.

[14] Guan, F., Ubon, C., Soma, R., Yu, Y., Liu, Y., Li, X. (2010): High-throughput UHPLCMS/MS method for the detection, quantification and identification of fifty-five anabolic and androgenic steroids in equine plasma. - J Mass Spectrometry 45: 1270-1279.

[15] Ishak, M. A., Omar, C. A. (2014): Effect of Testosterone Enanthate Injection and Castration on some Productive Traits of Karadi Lambs. - Journal of Zankoy Sulaimani 16 - Special Issue: $219-230$.

[16] Istasse, L., Evrard, P., Van Eenaeme, C., Gielen, M., Maghuin-Rogister, G., Bienfait, J. M. (1988): Trenbolone acetate in combination with 17 beta-estradiol: influence of implant supports and dose levels on animal performance and plasma metabolites. - J. Anim. Sci. 66(5): 1212-1222.

[17] Joint, FAO/WHO; Expert Committee on Food Additives, JECFA (1988): Evaluation of certain veterinary drugs residues in food. Thirty-second Report of the Joint FAO/WHO Expert Commitee on Food Additives. - WHO Technical Report Series 763, World Health Organization, Geneva.

[18] Liewellyn, W. (2006): Anabolic 2007. $6^{\text {th }}$ ed. - Molecular Nutrition, Jupiter.

[19] Lone, K. P., Van Ginkel, D. A. (1997): Natural sex steroids and their xenobiotic analogs in animal production; Growth, carcass quality, pharmacokinetics, metabolism, mode of action, residues, methods, and epidemiology. - Critical reviews in food science and nutrition 37(2): 93-209.

[20] MacVinish, L. J., Galbraith, H. (1988): The effect of implantation of trenbolone acetate and oestradiol-17 $\beta$ in wether lambs at two initial live weights on concentrations of steroidal residues and blood glucose, urea and thyroid hormones. - Anim. Prod. 47: 75-85.

[21] Melloni, R. H., Conner, D. F., Hang, P. T., Harrison, R. J., Ferris, C. F. (1997): Anabolic androgenic steroid exposure during adolescence and aggressive behavior in golden hamsters. - Physiol Behav 61: 359-364.

[22] Mohammed, H. H., Badawi, M. E., El-Tarabany, M. S., Rania, M. (2016): Effects of boldenone undecylenate on growth performance, maintenance behaviour, reproductive hormones and carcass traits of growing rabbits. - Polish journal of veterinary sciences 19(2): 245-251.

[23] Mottram, D. R., George, A. J. (2000): Anabolic steroids. - Best Pract. Res. Clin. Endocrinol. Metab. 14: 55-69.

[24] Nahed, S. T., Emad, M. A., Emad, W. G., Salah, S. E. (2010): Effect of anabolic steroids, boldenone undecylenate on reproductive performance of male rabbits. - Journal of Reproduction and Infertility 1: 08-17.

[25] National Research Council, NRC (1977): Nutrient Requirements of Rabbits. - Second Revised Washington, DC Edition. The National Academies Press. doi: 10.17226/35.

[26] Omar, C. A. (2012): Effect of Testosterone Enanthate Injection on Some Productive, Physiological Traits and Their Residue in The Tissues of Karadi Lambs. - Doctoral Dissertation, University of Sulaimani. 
[27] Paris, A., Andre, F., Antignac, J. P., Le Bizec, B., Bonneau, M., Briant, C., Caraty, A., Chillard, Y., Cognie, Y., Combarnous, Y., Cravedi, J. P., Fabre-Nys, C., Fernandez-Suarez, A., Fostier, A., Humblot, P., Laudet, V., Leboeuf, B., Louveau, I., Malpaux, B., MartinatBotte, F., Maurel, M. C., Pelicier-Rubio, M. T., Picard-Hagen, N., Pinault, L., Pinel, G., Ponsard, C., Popot, M. A., Schmidely, P., Toutain, P. L., Zalko, D. (2006): Hormones and growth promoters: from physiologic to risk assessment. - INRA. Prod. Anim. 19: 149-240.

[28] Sadek, A. I., Ismail, H. M., Sallam, H. N., Salem, M. (1998): Survey of hormonal levels in meat and poultry sold in Alexandria, Egypt. - Etern. Mediterranean Health 4(2): 234-239.

[29] Shahidi, N. T. (2001): A review of the chemistry, biological action, and clinical applications of anabolic-androgenic steroids. - Clin. Ther. 23: 1355-1390.

[30] Shimomura, K., Shimada, M., Hagiwara, M., Harada, S., Kato, M., Furuhama, K. (2005): Insights into testicular damage induced by ethinylestradiol in rats. - Reproductive Toxicology 20: 157-163.

[31] Simontacchi, C., Perez de Altamirano, T., Marinelli, L., Angeletti, R., Gabai, G. (2004): Plasma steroid variations in bull calves repeatedly treated with testosterone, nor testosterone and oestradiol administered alone or in combination. - Veterinary Research Communications 28: 467-477.

[32] Snyder, P. J. (2008): Use of Androgens and Other Drugs by Athletes. - Up To Date, October 2008.

[33] Takahashi, M., Tatsugi, Y., Kohno, T. (2004): Endocrinological and pathological effects of anabolic-androgenic steroid in male rats. - Endocrine Journal 51: 425-434.

[34] Tawfeek, M. I., El-Gaafary, M. N., Abdel-Hamid, M. Y. (1994): Effect of testosterone injection on pre and post- sexual maturity in male rabbits. - Options Mediterraneennes, International Conference of rabbit production in hot climates, Cairo (Egypt): 367-373.

[35] Thabet, N. S., Abdelrazek, E. M., Ghazy, E. W., Elballal, S. S. (2010): Effect of the anabolic steroid, boldenone undecylenate on reproductive performance of male rabbits. $-\mathbf{J}$ Reprod Infertility 1: 8-17.

[36] Thienpont, L., Verhseghe, P., Brussel, K. V., De-Leenheer, A. (1998): Efforts by industry toward standardization of serum estradiol-17 f measurements. - Clin Chem. 44: 671-674.

[37] Tousson, E., Alm-Eldeen, A., El-Moghazy, M. (2011a): p53 and Bcl-2 expression in response to boldenone induced liver cells injury. - Toxicology and Industrial Health 27: 711-718.

[38] Tousson, E., El-Gerbed, M. S. A., Shaleby, S. (2011b): Effects of maturity on histopathological alteration after a growth promoter boldenone injection in rabbits. Journal of American Science 7: 1074-1080.

[39] Tousson, E., El-Moghazy, M., Massoud, A., Akel, A. (2012): Histopathological and immunohistochemical changes in the testes of rabbits after injection with the growth promoter boldenone. - Reprod. Sci. 19: 253-259.

[40] Urhausen, A., Torsten, A., Wilfried, K. (2003): Reversibility of the effects on blood cells, lipids, liver function and hormones in former anabolic-androgenic steroid abusers. Journal of Steroid Biochemistry and Molecular Biology 84: 369-375.

[41] XLstat, 752 (2010). 